\title{
IX. Notes on some recent improvements of the steam-engines in Cornwall
}

\section{W. Jory Henwood F.G.S.}

To cite this article: W. Jory Henwood F.G.S. (1831) IX. Notes on some recent improvements of the steam-engines in Cornwall , Philosophical Magazine Series 2, 10:56, 97-103, DOI: $10.1080 / 14786443108675690$

To link to this article: http://dx.doi.org/10.1080/14786443108675690

里 Published online: 10 Jul 2009.

Submit your article to this journal $₫$

Џll Article views: 1

Q View related articles 두 
IX. Notes on some recent Improvements of the Stean-Engines in Cornwall. By W. Jory Hrewoon, F.G.S. Member of the Royal Geological Society of Cornwall.

To Richard Taylor, Esq. F.S.A. F.L.S. \&c.

\section{Dear Sir,}

THE same excuse which was offered by $\mathrm{Mr}$. Farey for his long silence on the subject of my paper* may, perhaps, now serve for mine on that of hist. I shall not attempt a regular discussion of his papers, as the digressions and the many objects they embrace, would, I fear, be unsuitable to your pages, and tiresome to your readers. I purpose confining myself to the various alterations and improvements which have been made in this county since Messrs. Boulton and Watt, and their agents, ceased to superintend the steamengines on our mines; with the addition of a few incidental observations on some of Mr. Farey's statements.

In my former communication to you on this subject, I said that " variation in the elasticity of the steam employed by no means affects the invention [my views would have been more correctly expressed, had I said the merit or principle of the invention] of expansive working ;" and, notwithstanding Mr. Farey's indignant attempts, he has advanced nothing which bears the semblance of proof of the contrary.

Mr. Farey sayst, Mr. Watt " proposed in 1782 to work his engines by stopping the supply of steam when the piston had only moved one-fourth of its course." Will that gentleman particularize the engines in this county which now expand more than three-fourths of their stroke? "Mr. Watt's engines with such boilers" (which will not retain steam of more than $3 \frac{1}{6}$ pounds per' square inch above the atmosphere) "cannot be made to exert a competent power to drain deep mines, unless the supply of steam to the cylinder is continued until the piston has run through more than half its course $f . "$ This I humbly apprehend will depend on the size of the engine, and the weight to be lifted. I hope I shall not be charged with "altering" this sentence so as to make it "very indefinite."

In 1801-í, Captain Trevithick erected a high-pressure engine of small size at Marazion, which was worked by steam of at least 30 pounds on the square inch above atmospheric pressure. In 1804, as Mr. Farey admits $\delta$, the same gentleman introduced his celebrated and valuable wrought-iron

* Phil. Mag. and Annals, N.S. vol. vii. p. 323.

+ Ibid. p. 421, and vol. viii. p. 305.

† Ibid. p. 309.

I Ibid. p. 313.

N.S. Vol. 10. No. 56. Aug. 1831. 
98 Mr. W. J. Henwood's Notcs on some recent Improvements

cylindrical boilers*, now universally used in this county. To these, every one at all acquainted with the Cornish improvements ascribes a great part of the saving we have obtained. This will further appear from an extract from a valuable work edited by John Taylor, Esq. F.R.S. t: the monthly consumption of coal in Dolcoath mine was in

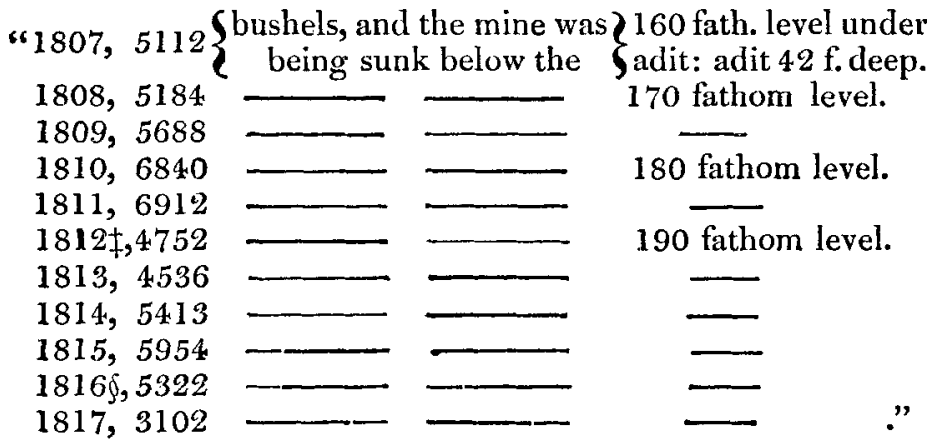

The alteration in the boilers, was the introduction of Capt. Trevithick's cylindrical boilers in place of the common rogggon boilers, which had until then been there in use.

In $181 \mathrm{l}-12$, Capt. Trevithick erected a single acting engine of 25-inches cylinder, working with but two valves (the exhausting valve being wanting) at Huel Prosper Mine in the parish of Gwithian, which of course had a cylindrical boiler, in which the pressure of steam was more than 40 pounds on the square inch above atmospheric pressure; and the engine was so loaded that it worked full seven-eighths of the stroke expansively. Mr. Woolf, as Mr. Farey states \|, came to reside in Cornwall about the year 1813, and his " first engines for pumping water from mines were set up by him in 1814, at Wheal Abraham and at Wheal Vor mines in Cornwall ; they had each two cylinders."

If the use of high-pressure steam acting expansively were a part of Mr. Woolf's patent, to which he could establish a legal and exclusive right; why did he not prefer a claim on Capt. Trevithick, or the adventurers in Huel Prosper Mine, who were using an engine of that description before that gentleman's arrival in Cornwall? The answer is obvious. Mr. Taylor remarks $\pi$, "During the whole of this year (1814),

- Phil. Mag. and Annals, N.S. vol, i. p. 127. † Records of Mining, p. 163. f Alteration in the boilers this year.

$\S$ In this year the old engine was replaced by a new one;- - of this more bereafter.

7 Records of Mining, p. 156. 
Jeffery and Gribble's engine at Stray Park performed the best duty, being the first that reached 35 millions, and maintaining for twelve months an average rate of 32 millions. Woolf's engine at Wheal Abraham was first reported in October in this year, and performed 34 millions. Number of engines reported, 29 ; average duty, 20,534,282." In the early part of 1816 , a single engine of 76-inch cylinder was erected at Dolconth mine by Messrs. Jeffree and Gribble (see preceding note), in place of an old and defective double one; which accounts for the diminished consumption of coal which the extract from $\mathrm{Mr}$. Taylor's notice of Dolcoath exhibits. In the same year Mr. Woolf replaced an old engine of 63-inch cylinder, but which had for a short time previously been worked by higher steam than usual, with one of 66-inch cylinder at Huel Abraham: the latter, if I am not mistaken, was set to work about the 12th of November.

I believe I have now satisfactorily shown that Mr. Woolf, instead of being the first to introduce the expansive action of steam in one cylinder, was positively preceded several years by Capt. Trevithick, and probably so, a short time, by Messrs. Jeffree and Gribble. Mr. Farey says, "He" (Mr. Woolf) " altered another old engine at Wheal Unity, by adding a small cylinder to it; the performance was improved in about the same degree as that of the old engine with one cylinder *." Perhaps Mr. Farey may not be aware that after being altered the Huel Unity engine did not answer expectation, and the nossels which Mr. Woolf had put in were thrown out and replaced by others; this only made the matter worse, for the engine would not then keep the water (" in fork"); to remedy the defect these were removed, and those first put in were replaced. But, to mend the matter, for several years before the engine was stopped, the use of the small cylinder was dispensed with, and the engine worked as a common Watt's single engine; in which mode it is at present worked on Oppie's shaft in Poldice mine.

Whilst on the subject of alterations, I may remark that Mr. Woolf had intended adding a small cylinder to the old engine (4.8-inch cylinder, single) at Huel Vor but the untoward result of his experiment at Huel Unity, prevented his making the attempt, although a cylinder was purchased for the purpose. This was subsequently, after much labour in enlarging the apertures, used by Messrs. Jeffree and Gribble as cylinder for a small double acting rotatory engine erected to move a stamping apparatus on the same mine, where it is

* Phil. Mag. and Annals, N.S. vol. viii. p. 312. 
$100 \mathrm{Mr}$. W. J. Henwood's Notes on some recent Imlprovements

still at work. Mr. Farey continues *, "In a short time after Mr. Woolf's patent expired, most of the old Boulton and Watt's engines in Cornwall were altered to work by highpressure steam on his system : some few had an extra cylinder added." Instead of the pressure of steam in general use being raised at that period, I assert no such alteration took place in a more marked degree, then, than had before obtained; and the alteration which at all took place was not in consequence of Mr. Woolf's assertions or performances, but of those of Capt.Trevithick. Will Mr. Farey name an engine to which a cylinder was added (that it might be worked on what he calls Mr. Woolf's system) after the expiration of that patent? He proceeds $t$, "The advantage of the change from low-pressure to high-pressure steam, on Mr. Woolf's system, was manifest in all cases; but it was greater or less, according as the steam was used stronger and with more or less expansive action." Now, I maintain that there is not a shadow of ground for this assertion, and I challenge Mr. Farey to prove its accuracy. He says $\dot{\text { I, " }}$ "Previous to 1826 the steam cases were not clothed, but exposed to the air." That the steam cases of Boulton and Watt's engines were covered with lath and plaster whited on the outside, is notorious; their steam pipes were also encircled with straw ropes plastered and whited. The steam case at Dolcoath engine was surrounded with a casing of sheetiron; the interval of about four inches being filled with straw, hemp, saw-dust, and other imperfect conductors of heat. Mr. Farey says $\S$, "Mr. Hornblower, who practised that system" (expansive working) " in two cylinders, did not succeed so well as Mr. Watt himself, who only used one cylinder." I repeat, that " variation of the elasticity of steam employed by no means affects the principle of the invention;" the superiority of one cylinder over two being proved with low-pressure steam, it appears to me "ignorance in spite of experience" to expect a contradictory result by variation of tension only; and, still stumbling over the results of his own experiments as well as those of Messrs. Watt and Hornblower, Mr. Woolf's engine with two cylinders at Huel Alfred was a signal failure.

The improvements which came prominently into notice in 1827 were commenced by Capt. Grose, at Huel Hope mine in Gwinear parish, in 1825. They do not in any part consist, as Mr. Farey states $\|$, in " using better boiler"s;" for they are

* Phil. Mag. and Annals, N.S. vol. viii. p. 312.

+ Ibid. p. 312-313. $\quad \oint$ Ibid. p. 312. note.

+ Ibid.

II Ibid.313. 
precisely similar to those which he before says* were " first brought into use for high pressure steam by $\mathrm{Mr}$. Trevithick in 1804;" but in different arrangement of the flues $\uparrow$ round them; first introduced at Huel Hope, afterwards at Huel Towan, and subsequently in many other mines (the Consolidated, Huel Vor, \&c.); in some degree by more attention to the temperature of the hot well; and in a great proportion by carefully covering all the vessels containing dense steam with bodies which transmit heat very slowly.

That these originated with Capt. Grose, and were borrowed from him (without acknowledgement) by Mr. Woolf and others, will appear from the following extracts from Messrs. Lean's monthly reports.

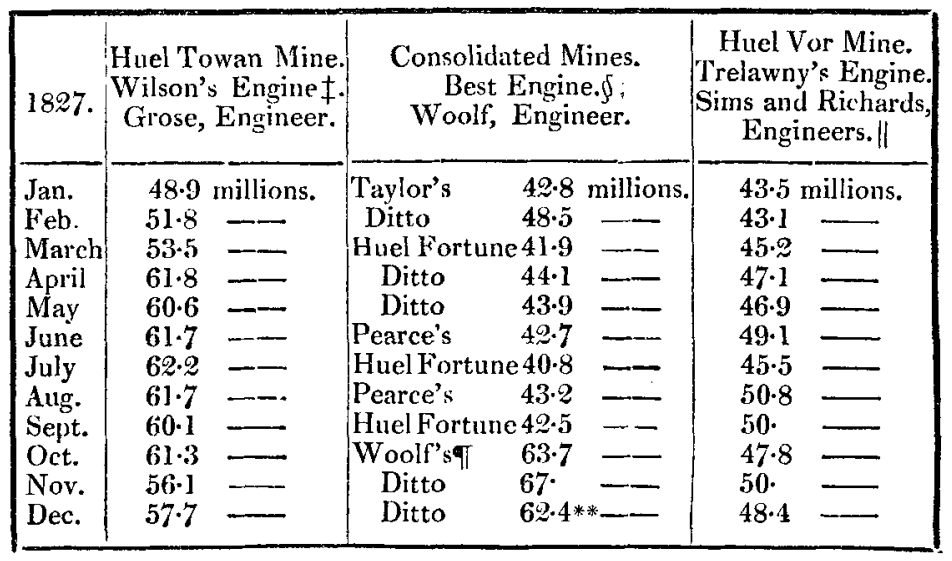

Millions.

1827: average of all the pumping engines reported $31 \cdot 9$ _ Huel Towan, Wilson's engine ...... 58.1 _ Consolidated Mines, 12 months' average of best engine ....... $\} 4.8 \cdot 6$

Woolf's engine $\mathbb{1}$........................ 64.4

Huel Vor Trelawny's engine.......... $4.7 \cdot 2$

* Phil. Mag. and Annals, N.S. vol. viii. p. 313, note.

+ Brewster's Journal, vol. ix. p. 159.

Wilson's engine was at that time the best on Huel Towan.

In the first nine months; the same engine was not every month the best.

II Trelawny's engine is the best on Huel Vor.

I Woolf's engine was not reported until October 1827.

** At an experiment made by some Cornish engineers in this month the dity was $63 \cdot 6$ millions. 


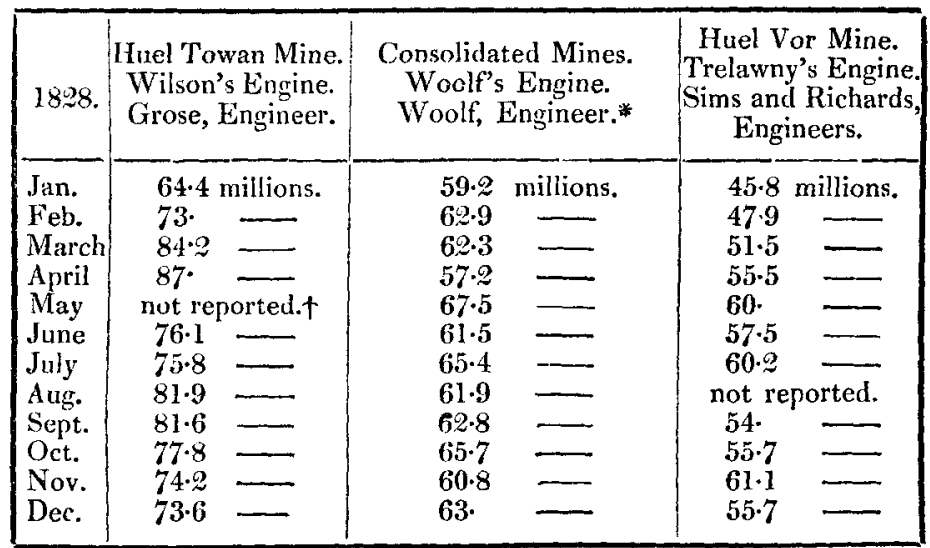

Millions.

1828: average of all the pumping engines reported $37 \cdot 2$ _ Huel Towan, Wilson's engine... $77 \cdot 2$ _ Consolid. Mines, Woolf's engine $62 \cdot 5$ - Huel Vor, Trelawny's engine...... 55.

I think the foregoing details prove, not only that Captain Grose led the van of the more recent improvements, but that he has kept far in advance of its strides. The importance of the saving thus obtained cannot be more plainly shown than by the following extract from Mr. Taylor's valuable " Records" $\neq$. "In 1825, all the drainage of the Consolidated Mines was effected by three engines only; they were hard pressed by the increased depth of the mine and quantity of water, and derangement happened, which, added to the bad state of some boilers, and the pit-work, which suffered from the engines being unavoidably worked too fast, the duty of the engines fell off considerably, and, as the reports will show, did not average quite 30 millions; at that time the monthly consumption was

Job's engine (90-inch cylinder) 4992 bushels.

$\begin{array}{llll}\text { Pearce's do. } & (58 & \text { do. } & \text { ) } 3615 \\ \text { Bawden's do. } & (90 & \text { do. } & \frac{8427}{17034}\end{array}$

" At the present time (1829) six engines are at work, as, to remedy the evils above stated, and to provide for sinking

* For all 1828, it took the lead of the Consols'. engines.

+ In this month an experiment was made by Cornish engineers, duty 87.2 millious; and in April 1830 by $\mathrm{Mr}$. Rennie and myself, duty $92,260,202$ by calculation, and by water delivered as determined by a float $83,602,022$.

$\neq$ Records of Mining. p. 164. 
deeper, three additional ones have been erected, and the consumption of fuel now stands as under, the mines being 20 fathoms deeper than in 1825:

Job's engine (90-inch cylinder) about 2050 bushels.

Pearce's do. (65 do. )(altered) 2130

Bawden's do. (90 do. ) about 2050

Taylor's do. (70

Woolf's do. $(90$

Shears's do. (70 do.

1480

do. ?

$1710--$

do. )

$\frac{1180}{10,600}$

"The average duty of the six engines is now reported at more than 50 millions." This difference $I$ attribute entirely to Capt. Grose's improvements. Mr. Farey has thought fit to charge me* with keeping back the fact of our engines having only one cylinder, and being worked with high-pressure steam, acting expansively. If he will refer to Brewster's Journal, vol. ix. p. 160, and vol. x. p. 42, he will find papers (which although inaccurate in some minor details are substantially correct) in which the elasticity of the steam employed is particularly mentioned. He has also said that I have, in quoting, "altered" his expressions, so as to make them "very indefinite" + . I believe my quotations present his ideas in quite as defnite a form as that in which they stand in the original; and I do not base this assertion on my own opinion only.

I may now be asked, in what respect Mr. Woolf has been a benefactor to Cornwall? I reply, In introducing accurate workmanship and some attention to proportion in the construction of engines, both which disappeared on Messrs. Boul. ton and Watt's removal. These I take to be the only benefits he has conferred on the county; but they are favours of no mean order, as those who know the state of the engines in Cornwall, before his arrival in the county, will readily admit.

I pass over some points of minor importance on which I could have desired to make a remark or two, as I fear I have already trespassed too long on your patience, and I am half ashamed that the discussion has assumed so unconnected a form; but however much 1 may be disposed to enter further upon it, I shall deny myself the honour, unless the inquiry be in future directed to but one point at a time. Yours, \&c.

Perran Wharf, near Truro,

WM. J. HenwoOd. April 11, 1831.

* Phil. Mağ. and Annals, N.S. vol. vii. p. 423.

+ Ibid. p. 422. 